\title{
Olefin Hydrogenation with Iron Carbonyls as Catalysts
}

\author{
I.M. Baibich* and R.R.P. Garcia \\ Instituto de Química, Universidade Federal do Rio Grande do Sul, \\ Av. Bento Gonçalves 9500, 91501-970 Porto Alegre - RS, Brazil
}

Received: August 24, 1995; September 27, 1996

\begin{abstract}
O estudo de $\left[\mathrm{Fe}(\mathrm{CO})_{5}\right],\left[\mathrm{Fe}_{2}(\mathrm{CO})_{9}\right]$ e $\left[\mathrm{Fe}_{3}(\mathrm{CO})_{12}\right]$ como precursores catalíticos nas reações de hidrogenação do ciclohexeno e 1-hexeno foi efetuado. Um reator fotoquímico com fluxo de $\mathrm{H}_{2}$ e irradiação UV-vis foi usado no processo. Os espectros infravermelho das amostras mostraram a formação de $\left[\mathrm{Fe}(\mathrm{CO})_{4}\right.$ (olefina) $]$ e $\left[\mathrm{HFe}(\mathrm{CO})_{3}(\pi\right.$-alila) $]$ como intermediários. A atividade mostrada do $\left[\mathrm{Fe}_{2}(\mathrm{CO})_{9}\right]$ na hidrogenação do ciclohexeno foi maior $(66,6 \%)$ que a atividade dos outros ferrocarbonilas $(43,0 \% \text { [Fe(CO) })_{5}$, $\left.\left[\mathrm{Fe}_{3}(\mathrm{CO})_{12}\right]\right)$. A competição entre as reações de isomerização e hidrogenação na reação do 1-hexeno foi estudada. A velocidade de isomerização foi muito maior que a velocidade de hidrogenação e as espécies polinucleares promoveram isomerização mais rapidamente que o $\left[\mathrm{Fe}(\mathrm{CO})_{5}\right]$. As conversões em alcanos foram: $60,0 \%\left(\left[\mathrm{Fe}(\mathrm{CO})_{5}\right],\left[\mathrm{Fe}_{3}(\mathrm{CO})_{12}\right]\right)$ e $75,4 \%\left[\mathrm{Fe}_{2}(\mathrm{CO})_{9}\right]$, mostrando que, para a hidrogenação do 1-hexeno, uma maior atividade para $\left[\mathrm{Fe}_{2}(\mathrm{CO})_{9}\right]$ foi também encontrada.
\end{abstract}

The use of $\left[\mathrm{Fe}(\mathrm{CO})_{5}\right],\left[\mathrm{Fe}_{2}(\mathrm{CO})_{9}\right]$ and $\left[\mathrm{Fe}_{3}(\mathrm{CO})_{12}\right]$ as catalytic precursors in the hydrogenation reactions of cyclohexene and 1-hexene was investigated. A photochemical reactor with $\mathrm{H}_{2}$ flux and UV-vis continuous irradiation was used for these studies. The infrared spectra of the samples showed the formation of $\left[\mathrm{Fe}(\mathrm{CO})_{4}\right.$ (olefin) $]$ and $\left[\mathrm{HFe}(\mathrm{CO})_{3}(\pi\right.$-allyl) $]$ as intermediates. The activity of $\left[\mathrm{Fe}_{2}(\mathrm{CO})_{9}\right]$ in the hydrogenation of cyclohexene was higher $(66.6 \%)$ than the activity of the other iron carbonyls $\left(43.0 \%\left[\mathrm{Fe}(\mathrm{CO})_{5}\right],\left[\mathrm{Fe}_{3}(\mathrm{CO})_{12}\right]\right)$. The competition between isomerization and hydrogenation in the reaction of 1-hexene was studied. The isomerization rate was much higher than the hydrogenation rate and the polynuclear species provided faster isomerizations than $\left[\mathrm{Fe}(\mathrm{CO})_{5}\right]$. The alkane conversions were: $60.0 \%$ $\left(\left[\mathrm{Fe}(\mathrm{CO})_{5}\right],\left[\mathrm{Fe}_{3}(\mathrm{CO})_{12}\right]\right)$ and $75.4 \%\left(\left[\mathrm{Fe}_{2}(\mathrm{CO})_{9}\right]\right)$, showing that for the 1-hexene hydrogenation $\left[\mathrm{Fe}_{2}(\mathrm{CO})_{9}\right]$ also exhibited the highest activity.

Keywords: iron carbonyls, olefin hydrogenation, catalysis

\section{Introduction}

The utility of $\left[\mathrm{Fe}(\mathrm{CO})_{5}\right]$ and $\left[\mathrm{Fe}_{3}(\mathrm{CO})_{12}\right]$ as photocatalysts in the hydrogenation of alkenes has been known since the $1970 \mathrm{~s}^{1-4}$. Many unsaturated derivatives are produced in these reactions via the loss of $\mathrm{CO}$ groups from the iron carbonyls, and the actual catalyst is probably a reduced carbonyl species, such as $\left[\mathrm{Fe}(\mathrm{CO})_{\mathrm{x}}\right]$ or $\left[\mathrm{Fe}(\mathrm{CO})_{3}\right]^{5-10}$. Surprisingly, the photocatalytic activity of the dinuclear compound $\left[\mathrm{Fe}_{2}(\mathrm{CO})_{9}\right]$ has never been investigated. In this paper, we report our studies on the photocatalytic activity of $\left[\mathrm{Fe}_{2}(\mathrm{CO})_{9}\right]$ in the hydrogenation of cyclohexene and 1-hexene. Furthermore, comparative studies of the photocatalytic activities of $\left[\mathrm{Fe}(\mathrm{CO})_{5}\right]$ and $\left[\mathrm{Fe}_{3}(\mathrm{CO})_{12}\right]$ in these processes were also performed.

\section{Experimental}

A photochemical reactor made of Pyrex ${ }^{11}$ was used, and a mercury vapor lamp $(125 \mathrm{~W})$ was adapted to the reactor.

The reactions were conducted under $\mathrm{H}_{2}$ flux $\left(\mathrm{P}\left[\mathrm{H}_{2}\right]=1\right.$ atm), at $0{ }^{\circ} \mathrm{C}$, under continuous irradiation. All of the preparatory steps were undertaken under Ar atmosphere, and the reactor was purged with Ar for five minutes before use.

$\left[\mathrm{Fe}(\mathrm{CO})_{5}\right]$ was supplied by BASF. $\left[\mathrm{Fe}_{2}(\mathrm{CO})_{9}\right]$ and $\left[\mathrm{Fe}_{3}(\mathrm{CO})_{12}\right]$ were prepared as described in the litera ture $^{12,13}$.

The toluene solutions were $0.01 \mathrm{M}$ in iron and $0.1 \mathrm{M}$ in the olefin (cyclohexene or 1-hexene). The same iron atom 
amounts were used for the three iron carbonyls studied in order to allow the data to be compared.

IR spectra were taken with a Perkin- Elmer 1430 spectrophotometer ( $v_{\text {CO }}$ region, 2200-1900 $\mathrm{cm}^{-1}$ ). Samples were analyzed by capillary gas chromatography (HP5890A gas chromatograph, FID detector, $23 \mathrm{~m}$ x 0.25 mm, SE-30 capillary column, HP3392A integrator).

\section{Results and Discussion}

As previously reported ${ }^{10}$, the activity of the catalytic precursors $\left[\mathrm{Fe}(\mathrm{CO})_{5}\right],\left[\mathrm{Fe}_{2}(\mathrm{CO})_{9}\right]$ and $\left[\mathrm{Fe}_{3}(\mathrm{CO})_{12}\right]$ in the cyclohexene hydrogenation reaction shows that $\left[\mathrm{Fe}_{2}(\mathrm{CO})_{9}\right]$ is the most active of the iron carbonyls while the conversion values obtained for $\left[\mathrm{Fe}(\mathrm{CO})_{5}\right]$ and $\left[\mathrm{Fe}_{3}(\mathrm{CO})_{12}\right]$ are quite similar (Table 1).
Although $\left[\mathrm{Fe}_{2}(\mathrm{CO})_{9}\right]$ is highly insoluble in toluene, no insoluble material was seen in the reactor soon after the irradiation started $(\sim 1 \mathrm{~min})$. The absence of a heterogeneous component was confirmed by a mercury test ${ }^{14}$. The presence of an heterogeneous component would have been detected by the decrease in activity due to amalgam formation.

One possible explanation for the higher activity of $\left[\mathrm{Fe}_{2}(\mathrm{CO})_{9}\right]$ is that upon photochemical activation, the dinuclear species $\left[\mathrm{Fe}_{2}(\mathrm{CO})_{8}\right]^{15,16}$ is formed, together with $\left[\mathrm{Fe}(\mathrm{CO})_{4}\right]$. Since $\left[\mathrm{Fe}_{2}(\mathrm{CO})_{6}(\text { olefin })_{2}\right]$ derives from $\left[\mathrm{Fe}_{2}(\mathrm{CO})_{8}\right]^{17 \mathrm{a}, 18}$, this kind of intermediate might be present in the system, leading to high activity. In Scheme 1 it is suggested that the olefin dinuclear compound is part of the cycle as suggested by Wrighton and Mitchener ${ }^{17 \mathrm{a}}$. Thus, mono and dinuclear iron species could be present in the three systems. In

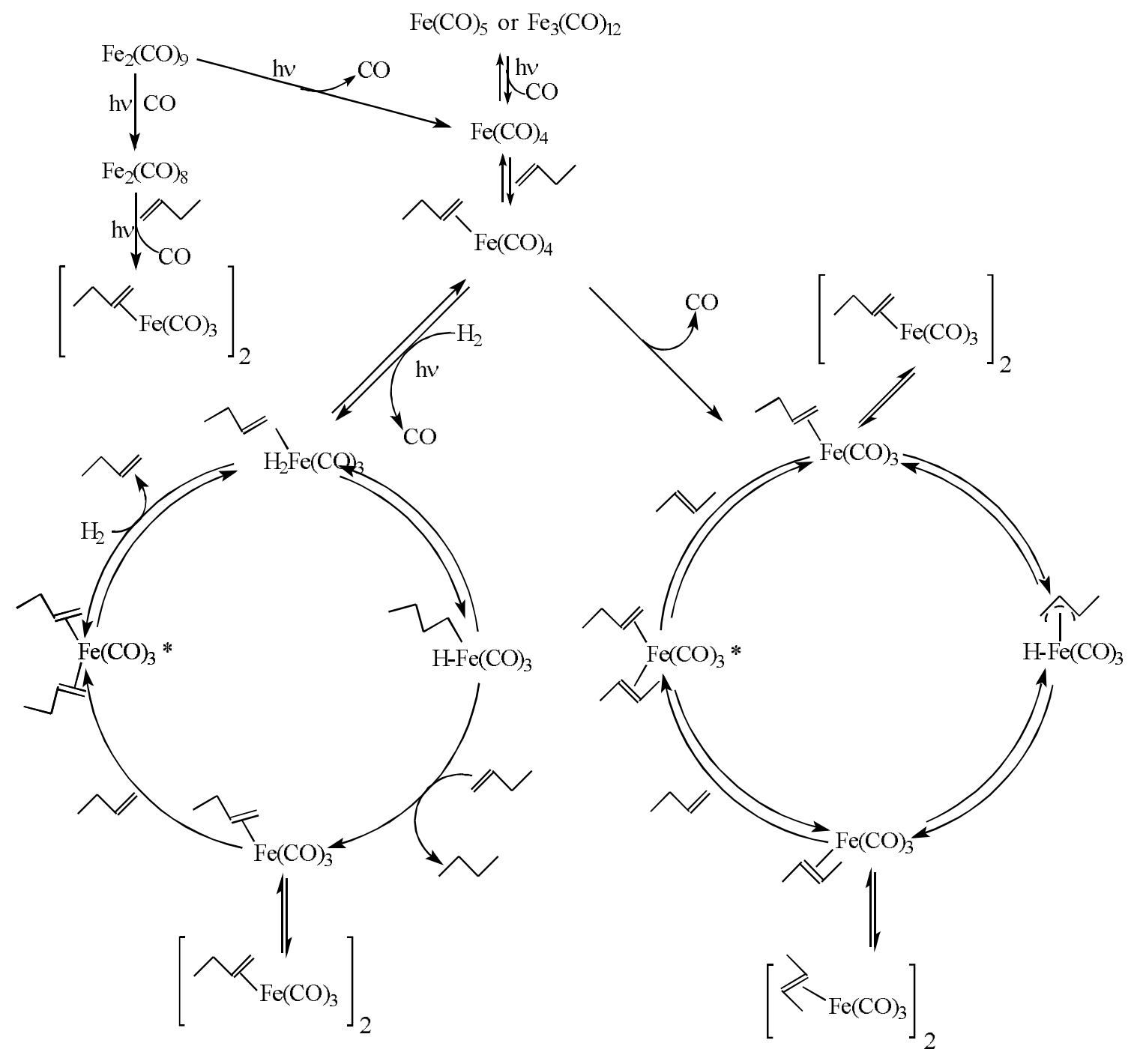

Hydrogenation

Isomerization

Scheme 1. Catalytic cicle for isomerization an hydrogenation reactions. *No evidence has been found for these species. 
the case of $\left[\mathrm{Fe}_{2}(\mathrm{CO})_{9}\right]$, the concentration of the dimeric species would be the highest, because of the photochemically induced $\mathrm{CO}$ dissociation fragmentation, whereas in the other cases, the dimeric species would be formed upon the condensation of two mononuclear fragments.

The IR spectrum of the solution from the cyclohexene reaction with $\left[\mathrm{Fe}(\mathrm{CO})_{5}\right]$ after $1 \mathrm{~h}$, shows bands which are characteristic of $\left[\mathrm{Fe}(\mathrm{CO})_{4}\right.$ (olefin)] $(2080,2025,2001$, and 1960 $\mathrm{cm}^{-1}$ ). The bands at 2060 and $2025 \mathrm{~cm}^{-1}$ correspond to $\left[\mathrm{Fe}_{3}(\mathrm{CO})_{12}\right]$. These bands are present in all of the reactions studied, and the formation of $\left[\mathrm{Fe}_{3}(\mathrm{CO})_{12}\right]$ may be due to the decomposition of the catalyst. There is a shoulder at 1945 $\mathrm{cm}^{-1}$, suggesting the presence of $\left[\mathrm{HFe}(\mathrm{CO})_{3}(\pi\right.$-allyl) $]$ (2064, 1994, and $\left.1945 \mathrm{~cm}^{-1}\right)$, but the overlap with the band at 1960 $\mathrm{cm}^{-1}\left(\left[\mathrm{Fe}(\mathrm{CO})_{4}(\right.\right.$ olefin) $\left.]\right)$ does not allow a conclusive band assignment. As observed in the case of $\left[\mathrm{Fe}(\mathrm{CO})_{5}\right]$, the reaction with $\left[\mathrm{Fe}_{2}(\mathrm{CO})_{9}\right]$ as the catalyst also showed bands due to $\left[\mathrm{Fe}(\mathrm{CO})_{4}(\right.$ olefin $\left.)\right]$ and $\left[\mathrm{Fe}_{3}(\mathrm{CO})_{12}\right]$. Furthermore, in this case, a well-defined band at $1945 \mathrm{~cm}^{-1}\left(\left[\mathrm{HFe}(\mathrm{CO})_{3}(\pi\right.\right.$-allyl)]) was observed. During the process, the intensity of this band does not change appreciably. In the case of the reaction with $\left[\mathrm{Fe}_{3}(\mathrm{CO})_{12}\right]$, the bands due to $\left[\mathrm{Fe}(\mathrm{CO})_{4}\right.$ (olefin)] and $\left[\mathrm{HFe}(\mathrm{CO})_{3}\left(\pi\right.\right.$-allyl)] (approx. $\left.1945 \mathrm{~cm}^{-1}\right)$ appear again. In all of the iron carbonyl reactions the presence of $\left[\mathrm{Fe}_{2}(\mathrm{CO})_{6}\right.$ (olefin $)_{2}$ ] could not be characterized due to the superimposition of the 2059 and 1982 bands on other bands in the spectra. All IR bands are in agreement with the data in the literature ${ }^{5,17}$. Fig. 1 shows the IR bands for the $\left[\mathrm{Fe}_{2}(\mathrm{CO})_{9}\right]$ reaction.

Regarding the three iron carbonyls, it was observed that during the first hour of reaction, 1-hexene suffered mainly

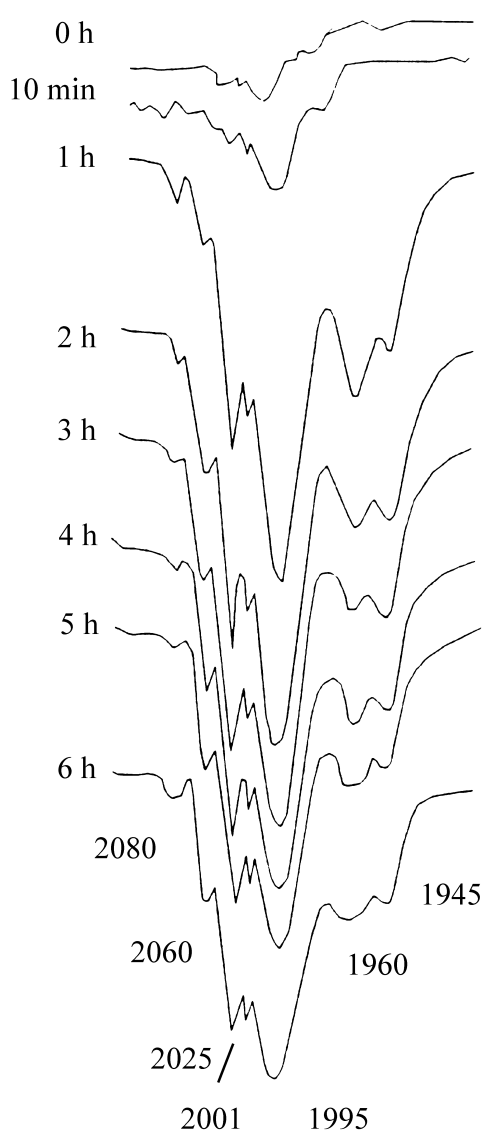

Figure 1. Infrared spectra in the $v(\mathrm{CO})$ region of the cyclohexene hydrogenation using $\left[\mathrm{Fe}_{2}(\mathrm{CO})_{9}\right]$ as the catalyst.

Table 1. Product conversions in the cyclohexene and 1-hexene hydrogenation reactions using $\left[\mathrm{Fe}(\mathrm{CO})_{5}\right],\left[\mathrm{Fe}_{2}(\mathrm{CO})_{9}\right]$, and $\left[\mathrm{Fe}_{3}(\mathrm{CO})_{12}\right]$ as catalytic precursors.

\begin{tabular}{lcccc}
\hline & & \multicolumn{3}{c}{ Conversion [\%] time } \\
\cline { 3 - 5 } Catalyst & Product & $1 \mathrm{~h}$ & $4 \mathrm{~h}$ & $8 \mathrm{~h}$ \\
\hline \multirow{3}{*}[\mathrm{Fe}(\mathrm{CO})_{5}]{} & cyclohexane & 15.75 & 32.10 & 41.95 \\
& hexane & 8.41 & 34.46 & 60.83 \\
& trans-2-hexene & 75.91 & 54.08 & 31.83 \\
& cis-2-hexene & 13.62 & 10.26 & 6.18 \\
\hline & cyclohexane & 32.11 & 59.80 & 66.60 \\
{$\left[\mathrm{Fe}_{2}(\mathrm{CO})_{9}\right]$} & hexane & 10.90 & 42.92 & 75.41 \\
& trans-2-hexene & 74.30 & 47.41 & 20.26 \\
& cis-2-hexene & 13.94 & 9.00 & 3.78 \\
\hline & cyclohexane & 15.25 & 31.90 & 42.75 \\
{$\left[\mathrm{Fe}_{3}(\mathrm{CO})_{12}\right]$} & hexane & 6.94 & 35.77 & 58.01 \\
& trans-2-hexene & 76.47 & 49.37 & 34.96 \\
& cis-2-hexene & 15.61 & 12.10 & 6.40 \\
\hline
\end{tabular}


isomerization and only $11 \%$ was converted to hexane. Afterwards, the hydrogenation process predominated (Table 1).

Polynuclear species require less energy to form compounds such as $\left[\mathrm{Fe}(\mathrm{CO})_{4}\right.$ (olefin) $]$, because the cleavage of the iron-iron bond demands less energy than that of the iron-CO bond $^{15}$, which explains the lower activity of $\left[\mathrm{Fe}(\mathrm{CO})_{5}\right]$ for isomerization. In the step where the hydrogenation reaction predominates (after $1 \mathrm{~h}$ of reaction), similar results were found for cyclohexene. In Scheme 1, possible mechanisms are suggested for these hydrogenation and isomerization processes, based on Refs. 5 and 17. It is suggested here that the step involving the equilibrium between $\left[\mathrm{Fe}(\mathrm{CO})_{3}\right.$ (olefin)] and $\left[\mathrm{Fe}(\mathrm{CO})_{3} \text { (olefin) }\right]_{2}$ is more important in the hydrogenation cycle, which explains why $\left[\mathrm{Fe}_{2}(\mathrm{CO})_{9}\right]$ is more active in hydrogenation than in isomerization reactions: when $\left[\mathrm{Fe}_{2}(\mathrm{CO})_{9}\right]$ is used, there is an increase in the $\left[\mathrm{Fe}(\mathrm{CO})_{3} \text { (olefin) }\right]_{2}$ concentration, and consequently the $\left[\mathrm{Fe}(\mathrm{CO})_{3}\right.$ (olefin) $]$ concentration increases.

The IR spectra for the 1-hexene reaction of the three iron compounds show a pattern which is analogous to that for the cyclohexene reaction. The bands characteristic of $\left[\mathrm{Fe}(\mathrm{CO})_{4}(1\right.$-hexene $\left.)\right],\left[\mathrm{HFe}(\mathrm{CO})_{3}(\pi\right.$-allyl $\left.)\right]$ and $\left[\mathrm{Fe}_{3}(\mathrm{CO})_{12}\right]$ can be observed.

All attempts to identify the wine-colored compound which precipitates under vacuum at $-78^{\circ} \mathrm{C}$ failed. As soon as the temperature rises, the wine-colored solid compound becomes green and the IR spectrum shows only $\left[\mathrm{Fe}_{3}(\mathrm{CO})_{12}\right]$ bands.

\section{Conclusions}

The photochemical activation of $\left[\mathrm{Fe}(\mathrm{CO})_{5}\right]$, $\left[\mathrm{Fe}_{2}(\mathrm{CO})_{9}\right]$, and $\left[\mathrm{Fe}_{3}(\mathrm{CO})_{12}\right]$ at low temperature $\left(0^{\circ} \mathrm{C}\right)$ and in the presence of olefins led to the formation of compounds that catalyze isomerization and hydrogenation processes.

Isomerization is faster than hydrogenation, but does not have any influence on the catalyst activity, as far as hydrogenation is concerned, which confirms that there are intermediates common to the two processes.

$\left[\mathrm{Fe}_{2}(\mathrm{CO})_{9}\right]$ shows the highest activity in the hydrogenation of both cyclohexene and 1-hexene. This leads to the conclusion that the dinuclear species $\left[\mathrm{Fe}_{2}(\mathrm{CO})_{6}(\text { olefin })_{2}\right]$ is important in the hydrogenation process.

\section{Acknowledgments}

Thanks to Prof. Ian S. Butler (McGill University - Canada) for the helpful suggestions, and to CNPq for fellowships and grants.

\section{References}

1. Frankel, E.N.; Emken, E.A.; Peters, H.M.; Davison, V.L.; Butterfield, R.O.J. Org. Chem. 1964, 29, 3292.

2. Frankel, E.N.; Emken, E.A.; Davison, V.L.; Butterfield, R.O. J. Org. Chem. 1965, 30, 2739.

3. Cals, M.; Moaz, N. J. Chem. Soc. A 1987, 1811.

4. Ogata, L.; Misono, A. J. Chem. Soc. Jpn. 1964, 85, 748 .

5. Schroeder, M.A.; Wrighton, M.S. J. Am. Chem. Soc. 1976, 98, 551.

6. Weiller, B.H.; Miller, M.E.; Grant, E.R. J. Am. Chem. Soc. 1987, 109, 1051.

7. Geoffroy, L.G.; Wrighton, M.S. In Organometallic Photochemistry; Academic Press; New York, 1979.

8. Austin, R.G.; Paonessa, R.S.; Giordano, P.J.; Wrighton, M.S. Acc. Chem. Res. 1978, 168, 189.

9. a) Graff, J.L.; Sauner, R.D.;Wrighton, M.S. J. Am. Chem. Soc. 1979, 101, 273; b) Nayak, S.K.; Burkey, T.J. Inorg. Chem. 1992, 31, 1125.

10. Baibich, I.M.; Buffon, R.; Gerbase, A.E. In $5^{\circ}$ Seminário Brasileiro de Catálise, Guarujá, SP, September 1989.

11. de Paoli, M.A.; Rodrigues, C.F. Química Nova 1978, $1,16$.

12. Braye, E.H.; Hübel, W. Inorg. Synth. 1966, 8, 178.

13. McFarlane, W.; Wilkinson, G. Inorg. Synth. 1966, 8, 181.

14. Crabtree, R.H.; personal communication.

15. Wrighton, M. Chem. Rev. 1974, 74, 401.

16. Poliakoff, M.; Turner, J.J. J. Chem. Soc. A 1971, 2403.

17. a) Mitchener, J.C.; Wrighton, M.S. J. Am. Chem. Soc. 1983, 105, 1065.; b) Wells, J.R.; Weitz, E. J. Phys. Chem. 1993, 97, 3084.

18. Muetterties, E.L.; Sosinsky, B.A.; Zamaraev, K.I. J. Am. Chem. Soc. 1975, 97, 5299. 